\title{
Physico-Chemical and Sensory Properties of Bread Prepared from Wheat and Unripe Plantain Composite Flours Fortified with Bambara Groundnut Protein Concentrate
}

\author{
Kiin-Kabari David Barine \\ Department of Food Science and Technology, Rivers State University of Science and Technology, Port Harcourt, Rivers State, Nigeria
}

Email address:

kabaridavid@yahoo.com

To cite this article:

Kiin-Kabari David Barine. Physico-Chemical and Sensory Properties of Bread Prepared from Wheat and Unripe Plantain Composite Flours Fortified with Bambara Groundnut Protein Concentrate. International Journal of Nutrition and Food Sciences.

Vol. 4, No. 5, 2015, pp. 594-599. doi: 10.11648/j.ijnfs.20150405.23

\begin{abstract}
Matured, unripe plantain (Musa paradisiaca) fruits from a local cultivar, "Agbagba" were processed into flour. Protein concentrates were prepared from the flour of Bambara groundnut (Vigna subterranean L. Verde) using the alkaline extraction process. Bread was produced from the substitution levels of wheat/plantain/Bambara groundnut protein concentrate (BGPC) flour blends $(100-30 \%, 0-40 \%$ and $0-30 \%)$, respectively and the physical, chemical and sensory properties of the product evaluated. The result showed that the loaf height, volume and specific volume decreased with an increase in the levels of plantain/BGPC flour blends. Loaf height decreased from $11.2 \mathrm{~cm}$ (sample A) to $6.2 \mathrm{~cm}$ (sample G) and loaf volume reduced from $2291.4 \mathrm{~cm}^{3}$ to $1238.6 \mathrm{~cm}^{3}$ for samples A and G, respectively. There was no significant difference in loaf height up to sample C (20\% PF and 10\% BGPC) when compared to the control (sample A). Specific volume also reduced with increasing levels of the blends from $6.3 \mathrm{~cm}^{3} / 100 \mathrm{~g}$ to $2.2 \mathrm{~cm}^{3} / 100 \mathrm{~g}$ for samples A and $\mathrm{G}$, respectively. There was a corresponding increase in loaf weight in all samples as the plantain flour and BGPC increased. There was no significant difference in loaf weight up to sample C which also represents $20 \%$ PF $10 \%$ BGPC when compared to the control (sample A). The protein content in the fortified bread increased progressively from $10.4 \%$ (sample A) to $17.3 \%$ (sample G). From the result, it was observed that the addition of $10 \% \mathrm{BGPC}$ in the formulation improved the protein content of the bread to $13.6 \%$. Fat content increased significantly from $0.76 \%$ to $2.51 \%$ (samples A and F), respectively with increase in the protein concentrate added. Ash, crude fibre and energy values were also observed to increase with increasing addition of BGPC $(0.76 \%-2.21 \%, 9.1 \%-11.29 \%$ and $276.88 \mathrm{kcal} / 100 \mathrm{~g}-282.43 \mathrm{kcal} / 100 \mathrm{~g}$ ), respectively. The sensory result showed that the bread produced from $15 \%$ BGPC and $25 \%$ plantain flour was acceptable with respect to flavour, crumb texture and general acceptability.
\end{abstract}

Keywords: Plantain Flour, Wheat Flour, Bambara Groundnut Protein Concentrate, Bread

\section{Introduction}

Protein deficiency is a major global problem particularly in developing countries like Nigeria. There are legumes and oilseeds which contain high level of protein that can be exploited in the formulation of plantain products. One of such legumes includes Bambara groundnut. This crop is an indigenous African grain legume and it is widely grown in Nigeria but it is less utilized because of the presence of antinutritional factors which interfere with protein digestibility and bioavailability of minerals [1,2]. Detailed compositional studies showed that the beans contain between $17-24 \%$ crude protein with a good balance of the essential amino acids and $6.8 \%$ of lysine and $1.3 \%$ of methionine [1] compared to soybeans or cowpea. Plant proteins are gradually gaining acceptance as food ingredients. These are often used to enhance nutritional value of foods [3] formulated from carbohydrate based ingredients such as plantain.

Plantain is one of the cheapest carbohydrate foods in terms of cost per hectare, per ton and per calorie. Adeniji et al., [4] observed that plantain hybrid (PITA 14) had the highest total energy of $373.2 \mathrm{kj} / 100 \mathrm{~g}$; which suggest that the new cultivars may constitute good raw materials for high energy food 
formulations. Many scientists have tried to determine the food value of plantain by carrying out proximate and detailed chemical analyses of unripe and ripe plantain including the peels. Adeniji et al., [5] reported that the protein content of both the hybrids and the local cultivar (Agbagba) were generally low - with a mean value of $2.94 \%$ and $3.06 \%$ for hybrids and local cultivar, respectively. However, it is important to fortify plantain food products with Bambara groundnut protein concentrate in other to increase the protein content and enhance acceptability.

Bread is considered a popular staple food consumed as part of the daily diet worldwide with over 9millon $\mathrm{kg}$ of bread produced annually [6]. It has become a staple food for many families in developing countries and a convenient item for use in protein fortification of diets of children suffering from protein - energy malnutrition. Srikantha \& Erdman [7] reported that fortifying wheat bread with oilseed and legume flours could minimize the necessities of large-scale importation of wheat and also enhance the nutrient composition of bread. Studies on the use of various oilseeds and legume flours, protein concentrates and isolates in bread making have been reported [ $8-10]$. These studies showed that $2-15 \%$ of non-wheat flour, up to $18 \%$ protein concentrate and isolates can be used in bread making without undesirable changes in rheological properties. One of the nutritional limitations of using wheat flour in bread making is that it is low in lysine. Fortification of bread with soy flour and other composite flour dramatically improves protein quality [11] and also improves the well-being of consumers. Twenty $(20 \%)$ replacement of wheat flour with defatted soy flour leads to significantly higher beany flavour in bread when compared to the control (white bread). In contrast, Shogren et al., [12] found that bread made with $30 \%$ soywheat composite flours was not significantly different in beany flavour from whole wheat bread. According to Olaoye et al., [13] bread produced with soy flour substitution up to $15 \%$ was nutritionally superior to that of whole wheat bread.

Composite flour from plantain/wheat flour blends have been used in bakery products, snacks and complementary food formulations [14]. These efforts were aimed at improving the protein content in particular and the overall nutritional value of the products. However, legumes and oil seeds contain very high protein but are less utilized because they are not easily digested and absorbed by man and animals. Therefore, the aim of this research is to produce bread from wheat and unripe plantain composite flours fortified with Bambara groundnut protein concentrate and to evaluate the physical, chemical and sensory properties of the resultant bread in other to ascertain the level of acceptability that will help to reduce the level of wheat flour.

\section{Materials and Methods}

\subsection{Materials}

A local cultivar (Agbagba) of plantain (Musa paradisiaca) was collected from the International Institute for Tropical
Agriculture, (IITA) High Rainfall Station; Onne, agroecology, located at lat, $04^{\circ} 43^{1} \mathrm{~N}$, long. $07^{\circ} 01$; E and $10 \mathrm{~m}$, near Port Harcourt, Rivers State and used for the study. Bambara groundnut (Vignasubterrenea L.) seeds were purchased from markets in Enugu, Enugu State, all in Nigeria.

\subsection{Methods}

\subsubsection{Preparation of Plantain Flour}

Plantain fruits (Agbagba cultivar), obtained from hand number 2 from the proximal end of the bunch, as recommended by Baiyeri \& Ortiz [15], were peeled manually with the aid of stainless steel kitchen knives and the pulp was cut into uniform slices with thickness of about $1.5 \mathrm{~mm}$, soaked in $1.25 \%$ sodium metabisulphite for $5 \mathrm{~min}$ to prevent discolouration and dried in air circulating oven (Gallenkamp $\mathrm{S} / \mathrm{No} 90 / 02 / 190, \mathrm{UK})$ at $65^{\circ} \mathrm{C}$ for $20 \mathrm{~h}$ according to the method of Adeniji et al., [4]. The dried samples were milled to pass a $0.25 \mathrm{~mm}$ sieve as earlier reported by Kiin-Kabari \& Giami [16] for non-wheat cookies.

\subsubsection{Preparation of Bambara Groundnut Flour}

Bambara groundnut flour was prepared using the method described by Barimalaa et al., [17]. The beans were soaked for $24 \mathrm{~h}$ in tap water and dehulled manually. The seeds were further boiled for $10 \mathrm{~min}$, (1:4 bean to water ratio) in a stainless steel pot, drained and dried at $50^{\circ} \mathrm{C}$ in an air circulating oven for $19 \mathrm{~h}$. The dried samples were milled (FOSS, Cyclotec 1093, Sweden) and sieved into flour using $0.25 \mathrm{~mm}$ sieves.

\subsubsection{Preparation of Protein Concentrates}

The protein concentrates from Bambara groundnut flour (BGF) were prepared using the alkaline wet extraction process described by Deshpande \& Cheryan [18] with little modification as reported by Giami \& Isichei [19], for fluted pumpkin seeds. Fifty grams of sample was suspended in $300 \mathrm{ml}$ of $0.04 \mathrm{M} \mathrm{NaOH}$ and the mixture was stirred at room temperature $\left(28 \pm 1^{\circ} \mathrm{C}\right)$ for $1 \mathrm{~h}$, using a mechanical shaker. The $\mathrm{pH}$ of the slurry was adjusted to 10.8 using $1.0 \mathrm{M} \mathrm{NaOH}$ and centrifuged at $3500 \mathrm{rev} . \mathrm{min}^{-1}$ for $25 \mathrm{~min}$ to obtain a residue and a supernatant. The residue was re-suspended in $0.04 \mathrm{M}$ $\mathrm{NaOH}(200 \mathrm{ml})$ and the extraction procedure repeated to increase the yield of protein. The $\mathrm{pH}$ of the combined extract was adjusted to 4.5 using $1 \mathrm{M} \mathrm{HCl}$ to precipitate more proteins. The mixture was centrifuged at $3500 \mathrm{rev} \mathrm{min}^{-1}$ for 15 min to yield a precipitate (protein concentrate) which was washed twice with distilled water, adjusted to $\mathrm{pH} 7$ using $1 \mathrm{M}$ $\mathrm{NaOH}$, then air - dried for $48 \mathrm{~h}$ at room temperature $\left(28 \pm 1^{\circ} \mathrm{C}\right)$ and stored at $4^{\circ} \mathrm{C}$ as earlier reported by Kiin-Kabari \& Giami [16].

\subsubsection{Preparation of Flour Blends}

Breads were prepared with graded levels of wheat/plantain flour fortified with Bambara groundnut protein concentrates. The graded levels ranged from $0-30 \%$ protein concentrates and $0-40 \%$ plantain flour with $100 \%$ wheat flour as the control. 
Table 1. Recipe for production of bread from flour blends samples.

\begin{tabular}{llllllll}
\hline Ingredients & A & B & C & D & E & F & G \\
\hline WF $(\mathrm{g})$ & 100 & 80 & 70 & 60 & 50 & 40 & 30 \\
PF $(\mathrm{g})$ & 0 & 15 & 20 & 25 & 30 & 35 & 40 \\
BGPC $(\mathrm{g})$ & 0 & 5 & 10 & 15 & 20 & 25 & 30 \\
Yeast $(\mathrm{g})$ & 1.25 & 1.25 & 1.25 & 1.25 & 1.25 & 1.25 & 1.25 \\
Salt $(\mathrm{g})$ & 1.50 & 1.50 & 1.50 & 1.50 & 1.50 & 1.50 & 1.50 \\
Sugar $(\mathrm{g})$ & 10.0 & 10.0 & 10.0 & 10.0 & 10.0 & 10.0 & 10.0 \\
Fat $(\mathrm{g})$ & 2.50 & 2.50 & 2.50 & 2.50 & 2.50 & 2.50 & 2.50 \\
Water $(\mathrm{ml})$ & 56.0 & 56.0 & 56.0 & 56.0 & 56.0 & 56.0 & 56.0 \\
\hline
\end{tabular}

Key: $\mathrm{WF}=$ Wheat flour, $\mathrm{PF}=$ Plantain flour, $\mathrm{BGPC}=$ Bambara groundnut protein concentrate.

\subsubsection{Production of Plantain/Wheat Flour Bread Fortified with Bambara Groundnut Protein Concentrate}

The batter method described by Ogazi [20] was used with modifications. This procedure was adopted using various levels of protein concentrate substitution ranging from 0 $30 \%$, as shown in Table 1 . The flour and ingredients were weighed out as indicated in the recipe. The yeast and a portion of the sugar were dissolved in warm water at $35^{\circ} \mathrm{C}$. The remaining sugar was dissolved separately. The flour, fat and salt were mixed together for $5 \mathrm{~min}$. The dissolved yeast/sugar solutions were added and the mixing continued for $30 \mathrm{~min}$. The resultant batter was scaled $(500 \mathrm{~g})$, proofed for $15-20 \mathrm{~min}$ and baked at $100^{\circ} \mathrm{C}$ for $1 \mathrm{~h}$.

\subsubsection{Physical Properties of the Bread}

Physical parameters measured include loaf height, loaf volume, loaf weight and specific volume. Loaf weights were measured by means of an electronic weighing balance (Model HL250 AZ and Coy Ltd, Korea). Loaf volume and specific loaf volume were measured $30 \mathrm{~min}$ after removal from the oven using the method of Giami et al., [9] and slightly modified by using pure rice grains instead of pearled barley. A box of fixed dimension $(24.00 \times 15.70 \times 18.95 \mathrm{~cm})$ of initial volume $7140 \mathrm{~cm}^{3}$ was put into a tray, half filled with rice grains, shaken vigorously four (4) times, then filled till slightly overfilled, so that the overspill fall into the tray. The box was shaken again twice then a rule was used to press across the top of the box once to give a level surface. The seeds were decanted from the box into a receptacle and weighed. These procedures were repeated three times and mean value for grain weight was noted $(\mathrm{Bg})$. A weighed loaf was placed in the box and weighed. Grains $(4500 \mathrm{~g})$ were used to fill the box and levelled off as before. The overspill was weighed and the weight obtained. The weight of seeds around the loaf and volume of seeds displaced by the loaf were calculated using the following equations.

Grains/seed displaced by Loaf $(\mathrm{L})=\mathrm{Bg}+$ Overspill weight $-4500 \mathrm{~g}$.

$$
\text { Volume of loaf }(\mathrm{V})=\frac{L \times 7140 \mathrm{~cm}^{3}}{B g}
$$

Specific volume of loaf $=$ V/loaf wt $\left(\mathrm{cm}^{3} / \mathrm{g}\right)$

\subsubsection{Sensory Evaluation of the Fortified Bread}

Sensory evaluation of the bread was carried out after baking using the method described by Giami \& Barber [21] for fluted pumpkin cookies. A panel of twenty (20) consumers comprising staff and student from Rivers State University of Science and Technology, Port Harcourt, Rivers State, Nigeria was used. Criteria for selection were that panelist were 18 years of age, regular consumers of bread and were neither sick nor allergic to any food. Panelists were trained in the use of sensory evaluation procedures. At each session, samples were served on white saucers, properly coded with 3-digit random numbers to prevent bias. The sensory attributes of the bread including crust/crumb colour, texture, flavour and overall acceptability was evaluated using a 9 - point hedonic scale with 1 representing the least score (dislike extremely) and 9 the highest score (like extremely) as described by Iwe [22]. Necessary precautions were taken to prevent carryover flavour during the tasting by ensuring that panelists rinse their mouth with water after each stage of sensory evaluation.

\subsubsection{Chemical Analysis}

Crude protein, moisture content, fat, ash and crude fibre content of the bread was determined according to the AOAC [23] method. Total available carbohydrate was determined using the Clegg Anthrone method as described by Osborne \& Voogt [24]. Energy was calculated using the Atwater factor as reported by Okoye [25].

\subsubsection{Statistical Analysis}

Results were expressed as mean values and standard deviation of three (3) determinations. Data were analysed using a one-way analysis of variance (ANOVA) using Statistical Packaging for Social Science (SPSS) version 20.0 software 2011 to test the level of significance $(\mathrm{P}<0.05)$. Duncan New Multiple Range Test was used to separate the means where significant differences existed.

\section{Results and Discussions}

\subsection{Physical Properties of the Bread}

Loaf volume, loaf height and specific loaf volume were observed to reduce with increase in the level of plantain/BGPC flour blends as shown in Table 2. Loaf height reduced from $11.2 \mathrm{~cm}$ (sample A) to $6.2 \mathrm{~cm}$ (sample $\mathrm{G}$ ), loaf volume reduced from $2291.4 \mathrm{~cm}^{3}$ (sample A) to $1238.6 \mathrm{~cm}^{3}$ (sample $\mathrm{G}$ ) and specific loaf volume also reduced from $6.3 \mathrm{~cm}^{3} / \mathrm{g}$ to $2.2 \mathrm{~cm}^{3} / \mathrm{g}$. This is probably due to the reduction in wheat protein of the various samples which translated to lower gluten content. The higher the gluten content of flour, the higher the ability of the flour to extend (elasticity) and retain the carbondioxide produced during fermentation thereby yielding a higher loaf volume. Similar observations had been reported by Ocheme et al., [10]. In this study, there was no significant difference in loaf height at $20 \% \mathrm{PF}$ and $10 \%$ BGPC (sample C) and sample B (15\% $\mathrm{PF}$ and 5\% BGPC) when compared to the control (sample A).

Reduction in bread volume and quality as a result of 
blending wheat flour with more than $5 \%$ oil seeds or legume flour and protein concentrates have been reported by various workers [26, 27]. An increase in loaf weight from $364.3 \mathrm{~g}$ (sample A) to 558.4g (sample G) was observed. As loaf height and volume reduced, there was a corresponding increase in loaf weight in all samples as the plantain flour and BGPC increased. However, there was no significant difference in loaf weight up to sample $\mathrm{C}$ which represents $20 \% \mathrm{PF}$ and $10 \% \mathrm{BGPC}$ when compared to the control (sample A).

Table 2. Physical characteristics of bread prepared from different levels of substitution of wheat/plantain/BGPC blends.

\begin{tabular}{lll|l|l}
\hline Samples & $\begin{array}{l}\text { Loaf height } \\
(\mathbf{c m})\end{array}$ & $\begin{array}{l}\text { Loaf volume } \\
\left(\mathbf{c m}^{3}\right)\end{array}$ & $\begin{array}{l}\text { Loaf } \\
\text { weight }(\mathbf{g})\end{array}$ & $\begin{array}{l}\text { Specific } \\
\text { volume } \\
\mathbf{c m}^{\mathbf{3}} / \mathbf{g}\end{array}$ \\
\hline A & $11.2 \pm 0.6^{\mathrm{a}}$ & $2291.4 \pm 0.5^{\mathrm{a}}$ & $364.3 \pm 1.2^{\mathrm{c}}$ & $6.3 \pm 0.6^{\mathrm{a}}$ \\
B & $10.7 \pm 0.6^{\mathrm{a}}$ & $2184.6 \pm 0.5^{\mathrm{a}}$ & $369.4 \pm 0.9^{\mathrm{c}}$ & $5.9 \pm 0.3^{\mathrm{a}}$ \\
C & $10.1 \pm 0.8^{\mathrm{ba}}$ & $2076.8 \pm 0.2^{\mathrm{b}}$ & $374.6 \pm 1.3^{\mathrm{c}}$ & $5.5 \pm 0.1^{\mathrm{a}}$ \\
D & $9.4 \pm 0.2^{\mathrm{b}}$ & $1948.3 \pm 0.7^{\mathrm{b}}$ & $426.6 \pm 1.1^{\mathrm{b}}$ & $4.6 \pm 0.7^{\mathrm{b}}$ \\
E & $7.2 \pm 0.2^{\mathrm{c}}$ & $1790.4 \pm 0.6^{\mathrm{c}}$ & $513.3 \pm 0.8^{\mathrm{b}}$ & $3.5 \pm 0.4^{\mathrm{c}}$ \\
F & $6.6 \pm 0.1^{\mathrm{c}}$ & $1246.2 \pm 0.2^{\mathrm{d}}$ & $542.7 \pm 1.4^{\mathrm{a}}$ & $2.3 \pm 0.4^{\mathrm{c}}$ \\
G & $6.2 \pm 0.3^{\mathrm{c}}$ & $1238.6 \pm 0.4^{\mathrm{d}}$ & $558.4 \pm 0.9^{\mathrm{a}}$ & $2.2 \pm 0.5^{\mathrm{d}}$ \\
\hline
\end{tabular}

a,b,c,d Means bearing the same superscript within the same column do not differ significantly $(\mathrm{p}>0.05)$.

$\pm=$ means \pm standard deviation of triplicate determination

Key: Samples: $\mathrm{A}=100 \% \mathrm{WF}$ (control); $\mathrm{B}=80 \% \mathrm{WF}, 15 \%$ PF, 5\% BGPC; C = 70\% WF, 20\% PF, 10\% BGPC; D = 60\% WF, 25\% PF 15\% BGPC; E = 50\% WF, 30\% PF, 20\% $\mathrm{BGPC} ; \mathrm{F}=40 \% \mathrm{WF}, 35 \% \mathrm{PF}, 25 \% \mathrm{BGPC} ; \mathrm{G}=30 \% \mathrm{WF}$, $40 \%$ PF, $30 \%$ BGPC.

Where $\mathrm{WF}=$ Wheat flour, $\mathrm{PF}=$ Plantain flour, $\mathrm{BGPC}=$ Bambara groundnut protein concentrate.

\subsection{Sensory Characteristics of the Bread}

Acceptable bread was prepared from wheat/plantain/BGPC flour blends containing up to $15 \%$ protein concentrate and $25 \% \mathrm{PF}$ (sample D) with regards to general acceptability as shown in Table 3. Crust colour showed no significant difference $(\mathrm{p}>0.05)$ up to $20 \%$ protein concentrate and $30 \% \mathrm{PF}$ (sample E) when compared to sample A $(100 \% \mathrm{WF})$. The crust colour developments occurring on the dough surface are mainly by thermal non enzymatic caramalization reaction and Millard reactions between reducing sugars and amino acids [28]. Excessive dark crust colour may result in unacceptable taste and flavour. However, only $5 \%$ protein concentrate and $25 \% \mathrm{PF}$ compared significantly with the control with regards to flavour. The crumb texture compared favourably with the control also up to $15 \%$ protein concentrate and $25 \%$ plantain flour (PF). This crumb texture which is represented by crumb firmness and denseness decreased with increase in PF and BGPC. Similar observations were reported by Shogren et al., [12]. Vittadini \& Vodovotz [29] concluded that $20 \%$ soy flour substitution can be used to produce bread without significantly affecting textural attributes of the crumb.

Table 3. Sensory scores for bread prepared from wheat/plantain/BGPC flour blends.

\begin{tabular}{llllll}
\hline Samples & $\begin{array}{l}\text { Crust } \\
\text { colour }\end{array}$ & $\begin{array}{l}\text { Crumb } \\
\text { colour }\end{array}$ & Texture & Flavour & $\begin{array}{l}\text { Overall } \\
\text { acceptability }\end{array}$ \\
\hline A & $8.4^{\mathrm{a}}$ & $8.2^{\mathrm{a}}$ & $7.8^{\mathrm{a}}$ & $8.0^{\mathrm{a}}$ & $7.9^{\mathrm{a}}$ \\
$\mathrm{B}$ & $8.2^{\mathrm{a}}$ & $8.0^{\mathrm{a}}$ & $7.6^{\mathrm{a}}$ & $7.9^{\mathrm{a}}$ & $7.7^{\mathrm{a}}$ \\
$\mathrm{C}$ & $7.8^{\mathrm{ba}}$ & $7.5^{\mathrm{b}}$ & $7.2^{\mathrm{a}}$ & $7.5^{\mathrm{b}}$ & $7.4^{\mathrm{b}}$ \\
$\mathrm{D}$ & $7.9^{\mathrm{a}}$ & $6.4^{\mathrm{b}}$ & $7.0^{\mathrm{ba}}$ & $8.2^{\mathrm{a}}$ & $8.1^{\mathrm{a}}$ \\
$\mathrm{E}$ & $7.8^{\mathrm{ba}}$ & $6.1^{\mathrm{b}}$ & $6.2^{\mathrm{b}}$ & $7.5^{\mathrm{b}}$ & $7.0^{\mathrm{b}}$ \\
$\mathrm{F}$ & $7.6^{\mathrm{b}}$ & $5.4^{\mathrm{c}}$ & $5.7^{\mathrm{b}}$ & $7.1^{\mathrm{b}}$ & $6.2^{\mathrm{c}}$ \\
$\mathrm{G}$ & $7.0^{\mathrm{c}}$ & $5.2^{\mathrm{c}}$ & $5.5^{\mathrm{b}}$ & $7.2^{\mathrm{b}}$ & $6.0^{\mathrm{c}}$ \\
\hline
\end{tabular}

Means bearing the same superscripts within the same column are not significantly different.

Key:

Samples: $\mathrm{A}=100 \% \mathrm{WF}$ (control); $\mathrm{B}=80 \% \mathrm{WF}, 15 \% \mathrm{PF}$, $5 \%$ BGPC; $\mathrm{C}=70 \% \mathrm{WF}, 20 \% \mathrm{PF}, 10 \% \mathrm{BGPC} ; \mathrm{D}=60 \%$ $\mathrm{WF}, 25 \%$ PF $15 \%$ BGPC; $\mathrm{E}=50 \% \mathrm{WF}, 30 \% \mathrm{PF}, 20 \%$ $\mathrm{BGPC} ; \mathrm{F}=40 \% \mathrm{WF}, 35 \% \mathrm{PF}, 25 \% \mathrm{BGPC} ; \mathrm{G}=30 \% \mathrm{WF}$, $40 \%$ PF, 30\% BGPC.

Where $\mathrm{WF}=$ Wheat flour, $\mathrm{PF}=$ Plantain flour, $\mathrm{BGPC}=$ Bambara groundnut protein concentrate.

\subsection{Chemical Analysis}

Crude protein in the fortified bread increased progressively from $10.4 \%$ (sample A) to $17.5 \%$ (sample G) as presented in Table 4. However, there was no significant difference $(\mathrm{p}>$ 0.05 ) between samples A, B and C. This result showed that $10 \%$ protein concentrate in the composite flour blends can provide bread with $13.6 \%$ crude protein. This level of protein content was higher when compared to $8.39 \%$ obtained by supplementing WF with $15 \%$ soy flour composite bread as reported by Olaoye et al., [13]. As well as the $9.60 \%$ obtained by replacing milk and egg with fresh Moringa leave paste in cookie production as reported by Emelike et al., [30]. However, successful use of soy ingredients as low cost protein supplements in bread is challenging due to the unpleasant off-flavour compounds found in soy beans [31, 32].

The fat content of the enriched bread increased significantly from $0.76 \%$ (sample A) to $2.51 \%$ (sample F), with increase in the level of protein concentrate added. This trend was also observed in ash $0.76 \%$ (sample A) to $2.21 \%$ (sample F) and crude fibre to be $9.1 \%$ (sample A) to $11.29 \%$ (sample D). Similar observations had been reported by Olaoye et al., [13] and Abioye et al., [33]. Higher fat value may be detrimental to long storage life of the product. The energy values also increased from $276.88 \mathrm{kcal} / 100 \mathrm{~g}$ to $282.43 \mathrm{kcal} / 100 \mathrm{~g}$. These values are low when compared to the energy requirement for a $55 \mathrm{~kg}$ woman in bed which is 420 kcal [34]. 
Table 4. Chemical composition of bread prepared from wheat/plantain/BGPC flour blends.

\begin{tabular}{llllllll}
\hline Samples & Crude protein (\%) & Moisture content (\%) & Fat (\%) & Carbohydrate (\%) & Ash (\%) & Crude fibre (\%) & $\begin{array}{l}\text { Energy } \\
\text { (kcal/100g) }\end{array}$ \\
\hline A & $10.4^{\mathrm{c}}$ & $18.4^{\mathrm{a}}$ & $0.8^{\mathrm{d}}$ & $60.6^{\mathrm{a}}$ & $0.8^{\mathrm{d}}$ & $9.1^{\mathrm{b}}$ & $276.9^{\mathrm{c}}$ \\
$\mathrm{B}$ & $11.2^{\mathrm{c}}$ & $18.7^{\mathrm{a}}$ & $1.3^{\mathrm{c}}$ & $58.4^{\mathrm{a}}$ & $0.9^{\mathrm{d}}$ & $9.5^{\mathrm{b}}$ & $276.9^{\mathrm{c}}$ \\
$\mathrm{C}$ & $13.6^{\mathrm{b}}$ & $18.2^{\mathrm{a}}$ & $2.3^{\mathrm{b}}$ & $56.1^{\mathrm{ba}}$ & $1.2^{\mathrm{c}}$ & $8.6^{\mathrm{c}}$ & $287.8^{\mathrm{a}}$ \\
$\mathrm{D}$ & $13.8^{\mathrm{b}}$ & $17.1^{\mathrm{b}}$ & $2.5^{\mathrm{a}}$ & $54.2^{\mathrm{b}}$ & $1.3^{\mathrm{b}}$ & $11.3^{\mathrm{a}}$ & $282.6^{\mathrm{b}}$ \\
E & $14.3^{\mathrm{b}}$ & $17.5^{\mathrm{b}}$ & $2.5^{\mathrm{a}}$ & $53.2^{\mathrm{b}}$ & $1.6^{\mathrm{b}}$ & $10.9^{\mathrm{a}}$ & $281.4^{\mathrm{b}}$ \\
F & $15.4^{\mathrm{b}}$ & $17.2^{\mathrm{b}}$ & $2.5^{\mathrm{a}}$ & $52.3^{\mathrm{c}}$ & $2.2^{\mathrm{b}}$ & $10.4^{\mathrm{a}}$ & $282.4^{\mathrm{b}}$ \\
G & $15.0^{\mathrm{b}}$ & $17.1^{\mathrm{b}}$ & $2.6^{\mathrm{a}}$ & $55.1^{\mathrm{b}}$ & $2.3^{\mathrm{a}}$ & $10.5^{\mathrm{a}}$ & $287.6^{\mathrm{a}}$ \\
\hline
\end{tabular}

Means bearing the same superscript within the same column are not significantly different.

\section{Key:}

Samples: $\mathrm{A}=100 \% \mathrm{WF}$ (control); $\mathrm{B}=80 \% \mathrm{WF}, 15 \% \mathrm{PF}$, $5 \%$ BGPC; $\mathrm{C}=70 \% \mathrm{WF}, 20 \% \mathrm{PF}, 10 \% \mathrm{BGPC} ; \mathrm{D}=60 \%$ WF, 25\% PF 15\% BGPC; E = 50\% WF, 30\% PF, 20\% $\mathrm{BGPC} ; \mathrm{F}=40 \% \mathrm{WF}, 35 \% \mathrm{PF}, 25 \% \mathrm{BGPC} ; \mathrm{G}=30 \% \mathrm{WF}$, $40 \%$ PF, $30 \%$ BGPC.

Where $\mathrm{WF}=$ Wheat flour, $\mathrm{PF}=$ Plantain flour, $\mathrm{BGPC}=$ Bambara groundnut protein concentrate.

\section{Conclusion}

Acceptable bread was produced from wheat/plantain/BGPC flour blends containing up to $15 \%$ protein concentrate and $25 \%$ plantain flour (sample D) with regards to general acceptability, flavour and crumb texture. Addition of $15 \%$ BGPC to bread generally improved the protein content compared with the control. This confirms that the bread so developed had a better nutritional value than the control and could be used to combat protein energy malnutrition and also reduce the level of wheat flour in bread production by $30 \%$. However, further research on the glycemic index of baked products from wheat/plantain flour blend enriched with Bambara groundnut protein concentrate is on-going.

\section{References}

[1] Poulter, N. H. (1981). Properties of some protein fractions from Bambara groundnut (Voandreiasubterrenea L. Thouars). Journal of the Science of Food and Agriculture, 32, $44-50$.

[2] Achinewhu, S. C \& Isichei, M. O. (1990). The nutritional evaluation of fermented fluted pumpkin seeds (Telfairiaoccidentalis Hook). Discovery and innovation, 2(3), $62-65$

[3] Jones, L. J. \& Tung, M. A. (1983). Functional properties of modified oilseed protein concentrates and isolates. Canadian Institute of Food Science Technology Journal, 16, 57 - 62.

[4] Adeniji, T. A, Sanni, L. O., Barimalaa, I. S. \& Hart, A. D. (2007). Nutritional composition of five new Nigerian Musa hybrid cultivars. Implications for adoption in human nutrition. Fruits. $62,135-142$.

[5] Adeniji, T. A., Barimalaa, I. S. \& Achnewhu, S. C. (2006). Physicochemical composition of green (unripe) plantain and banana hybrid fruits. Global Journal Pure Appl. Science, $12(1), 52-53$.
[6] Heenan, S. P., Dutour, J. P., Hamud, N., Harvey, W. \& Delahurry, C. M. (2008). The sensory quality of fresh bread; descriptive attributes and consumer perceptions. Food Research International, 41(3), 987 - 997.

[7] Srikantha, S. \& Erdman, J. W. (1984). The winged bean as an oil and protein source: A review, Journal of American Oil and Chemical Society, 61(3), $515-525$.

[8] Nmorka, G. O. \& Okezie, B. O. (1983). Nutritional quality of winged bean composite breads. Cereal Chemistry, 60, $198-$ 202.

[9] Giami, S. Y., Amasisi, T. \& Ekiyor, G. (2004). Comparison of bread making properties of flours from roasted and boiled African bread fruit (TreculiaafricanaDecne). Journal of Raw Materials Research, 1, 16-25.

[10] Ocheme, O. B., Oloyede, O. O. \& Mahmud, A. H. (2010). Production and evaluation of bread using blends of wheat flour and fermented plantain flour. Nigerian Food Journal, 28(2), $284-293$.

[11] Marhayekh, M., Malmoodi, M. R. \& Fntezari, M. H. (2008). Effects of fortification of deffated soy flour on sensory and rheological properties of wheat bread. International Journal of Food Science and Technology, 43(9), $1693-1698$.

[12] Shogren, R. I., Mohammed, A. A. \& Curiere, C. (2003). Sensory analysis of whole-wheat/soy flour breads. Journal of Food Science, 68(6), $2141-2145$.

[13] Olaoye, O. A., Onilude, A. A. \& Idowu, O. A. (2006). Quality characteristics of bread produced from composite flours of wheat, plantain and soybeans. African Journal of Biotechnology, 5(11), $1102-1106$.

[14] Sanni, S. A. \& Eniola, S. A. (2004). Sensory characteristics of plantain-wheat biscuits. In: Adegoke G. O., Sanni, L. O., Falade K. O., Uzo-peters P. I. (Eds). $28^{\text {th }}$ Annual Conference AGM Nigeria Institute for Food Science Technology, University of Ibadan, Nigeria.

[15] Baiyeri, K. P. \& Ortiz, (1996). Agronomic evaluation of plantain and other triploid musa, In: Creanen K; Ortiz R; Karamura E. B; Vuylsteke D. R (Eds), Proceedings of First International Conference on Banana Plantain Africa. Kampala Uganda, 12 18 Oct. 1996, Beta Hortic 540 (2000), 125 - 135.

[16] Kiin-Kabari D. B \& Giami S. Y (2015). Physico-chemical properties and in-vitro protein digestibility of non-wheat cookies prepared from Plantain flour and Bambara Groundnut Protein concentrate. Journal of food research, 4(20), $78-86$.

[17] Baramalaa, I. S., Achinewhu, S. C., Yibatama, I. \& Amadi, E. N. (1994). Studies on the solid substrate fermentation of Bambara groundnut (Vignasubterienea). Journal of Science, Food and Agriculture, 66, $443-446$. 
[18] Deshpande, S. S. \& Cheryan, M. (1984). Preparation and antinutritional characteristics of dry bean (Phaseolousvalgaris L.) protein concentrates. Plant Foods Human Nutrition, 54, $185-196$.

[19] Giami, S. Y. \& Isichei, J. (1999). Preparation and properties of flours and protein concentrates from raw, fermented and germinated fluted pumpkin (Telfoririaoccidentalis Hook) seeds. Plants Foods Human Nutrition, 454, 67 - 77.

[20] Ogazi, P. O. (1984). Plantain, production, processing and utilization. Paman Associate Publication Oxford, London UK, Edinburgh Melbourne, Aust. 566.

[21] Giami, S. Y. \& Barber, L. I. (2004). Utilization of protein concentrates from ungerminated and germinated fluted pumpkin (Telfoririaoccidentalis Hook) seeds in cookies formulations. Journal of the science of Food and Agriculture, 84, $1901-1907$.

[22] Iwe, M. O. (2002). Handbook of Sensory Methods and Analysis. Rejoin Communication Services, Enugu.

[23] AOAC. (2012). Official methods of analysis of AOAC International (19th ed.), Gaithersburg, M.D. USA.

[24] Osborne, D. R. \& Voogt, P. (1978). The analysis of nutrients in foods. London Academic Press, 130 - 134.

[25] Okoye, Z. S. C. (1992). Chemical and biochemical indices of food quality. In: Biochemical aspects of Nutrition 137: Prentice - Hall of India Private Ltd. New Delhi - 110001.

[26] Yue, P., Hettiarachy, N. \& D’Appolonia, B. L. (1991). Native and succinylated sunflower proteins used in bread baking. Journal of Food Science, 56(4), $992-998$.
[27] Chauhan, G. S., Zillman, R. R. \& Eskin, N. A. M. (1992). Dough mixing and bread making properties of quinoa-wheat flour blends. International Journal of Food Science and Technology, 27(6), $701-705$.

[28] Be-miller, J. N. \& Whistler, R. L. (1996). Carbihydrates. In: Fernnema O. R. (ed) Food Chemistry $3^{\text {rd }}$ Ed. New York. Marcel Dekker Inc. 157 - 253.

[29] Vittadini, E. \& Vodovotz, Y. (2003). Changes in the physicochemical properties of wheat and soy containing breads during storage as studied by thermal analysis. Journal of Food Science, 68(6), 2022 - 2027.

[30] Emelike, N. J. T., Uwa, F. O., Ebere, C. O. \& Kiin-Kabari, D. B. (2015). Effect of drying methods on the physico-chemical and sensory properties of cookies fortified with Moringa (Moringa olelfera) leaves. Asian Journal of Agriculture and Food Sciences, 3(4), $361-367$.

[31] Russel, T. A., Drake, M. A. \& Gerard, P. D. (2006). Sensory properties of whey and soy proteins. Journal of Food Science, $71(6), 5447-5453$.

[32] Ivanovski, B. Sectharaman, K. \& Duizer, L. M. (2012). Development of soy-Based Bread with acceptable sensory properties. Journal of Food Science, 71(1), 571 - 576.

[33] Abioye, V. F., Ade-Omowaye, G. O. \& Adesigbin, M. K. (2011). Chemical, physic-chemical and sensory properties of soy-plantain flour. African Journal of Food Science, 5(4), 176 -180 .

[34] FAO/WHO (1973). Energy and protein requirements. Report of Joint FAO/WHO Ad-hoc Export committee. World Health Organisation technical reports series, No. 522. 